\title{
A New Catalytic Combustion-type Carbon Monoxide Gas Sensor Employing Precious Metal-free CO Oxidizing Catalyst
}

\author{
Ayaka HOSOYA, Shinji TAMURA and Nobuhito IMANAKA* \\ Department of Applied Chemistry, Faculty of Engineering, Osaka University, 2-1 Yamadaoka, Suita, Osaka, 565-0871 Japan. \\ (Received on March 10, 2015; accepted on March 31, 2015)
}

\begin{abstract}
A new catalytic combustion-type $\mathrm{CO}$ gas sensor was devised by using the precious metal-free $\mathrm{CO}$ oxidizing catalyst of $15.9 \mathrm{wt} \% \mathrm{La}_{0.87} \mathrm{Co}_{1.13} \mathrm{O}_{3}$-loaded $\mathrm{Ce}_{0.67} \mathrm{Zr}_{0.18} \mathrm{Sn}_{0.15} \mathrm{O}_{2.0}$. Since the $15.9 \mathrm{wt} \% \mathrm{La}_{0.87} \mathrm{Co}_{1.13} \mathrm{O}_{3}$ loaded $\mathrm{Ce}_{0.67} \mathrm{Zr}_{0.18} \mathrm{Sn}_{0.15} \mathrm{O}_{2.0}$ catalyst oxidizes $\mathrm{CO}$ completely at $130^{\circ} \mathrm{C}$, the sensor showed smooth and reproducible response to $\mathrm{CO}$ gas at $\mathrm{ca} .130^{\circ} \mathrm{C}$. Moreover, the sensor exhibited a linear relationship between response and $\mathrm{CO}$ gas concentration, along with short 50\% response time of 20-40 s.
\end{abstract}

KEY WORDS: gas sensor; carbon monoxide; catalytic combustion-type sensor; precious metal-free.

\section{Introduction}

Carbon monoxide (CO) is a highly toxic gas which causes serious health damage even at low concentrations when it is inhaled. Since CO gas cannot be detected by our senses because of its colorless and odorless nature, detection equipment is always necessary to prevent accidents caused by the exposure to $\mathrm{CO}$. Therefore, it is desired to install compact and inexpensive $\mathrm{CO}$ sensor at every site where $\mathrm{CO}$ gas may be emitted.

Until now, the various types of compact $\mathrm{CO}$ gas sensors have been developed based on semiconductor, ${ }^{1,2)}$ potentiostat, ${ }^{3)}$ and catalytic combustion-type. ${ }^{4,5)}$ Although semiconductor-type CO gas sensors have merits of stable sensor performance with low cost, this type of sensor has a basic problem in gas selectivity because other coexisting gases also adsorb on the semiconductor surface which produces a signal as well as CO. Potentiostat-type $\mathrm{CO}$ gas sensor is nowadays widely used owing to its selective $\mathrm{CO}$ detection, but they cannot operate for a long period because of the eventual evaporation of liquid electrolyte in the device. In contrast, catalytic combustion-type $\mathrm{CO}$ gas sensor can show the stable sensing performance for a long period because of its simple detection system which is combined by a Pt coil and a $\mathrm{CO}$ oxidation catalyst. The detection mechanism is as follows. When $\mathrm{CO}$ gas is oxidized on the catalyst, combustion heat related to the amount of $\mathrm{CO}$ generates. Then, the temperature of the $\mathrm{Pt}$ coil coated with the catalyst rises by the generated combustion heat, causing the electrical resistance increase of the Pt coil. Since the resistance change should be approximately proportional to the temperature change, the sensor signal (resistance change) is also exactly proportional to the amount of $\mathrm{CO}$ gas oxidized by the catalyst, in other words, $\mathrm{CO}$ gas content in the measuring atmo-

* Corresponding author: E-mail: imanaka@chem.eng.osaka-u.ac.jp DOI: http://dx.doi.org/10.2355/isijinternational.ISIJINT-2015-134 sphere. However, conventional catalytic combustion-type sensors have a problem in selectivity. Because the traditional catalysts applied $\left(\mathrm{Pt} / \mathrm{Al}_{2} \mathrm{O}_{3}\right.$ or $\left.\mathrm{Pd} / \mathrm{Al}_{2} \mathrm{O}_{3}\right)$ can work at several hundred Celsius degrees at which other gases such as volatile organic compounds (VOCs) also burn out, leading to certain responses to other gases. For overcoming this problem, it is essential to develop the novel catalyst which can oxidize only $\mathrm{CO}$ at lower temperatures at which gases other than $\mathrm{CO}$ are not oxidized.

Recently, we have fabricated a low-temperature operative catalytic combustion-type $\mathrm{CO}$ gas sensor ${ }^{6)}$ by employing 10 $w t \% \mathrm{Pt} / \mathrm{Ce}_{0.68} \mathrm{Zr}_{0.17} \mathrm{Sn}_{0.15} \mathrm{O}_{2.0}$ as the $\mathrm{CO}$ oxidizing catalyst which was also developed by us. Since this catalyst oxidized $\mathrm{CO}$ completely at $65^{\circ} \mathrm{C}$, quantitative $\mathrm{CO}$ detection was successfully achieved at such a low temperature of $70^{\circ} \mathrm{C}$ with the $50 \%$ response time (the time required for the electrical resistance of the device to reach $50 \%$ of the steady value eventually obtained at a given CO gas level) of $130 \mathrm{~s}$. Moreover, we have succeeded in improving the response time ( $50 \%$ response time: $20-30 \mathrm{~s}$ ) of the sensor by adding the high thermal conductive material of aluminum nitride (AIN) as an intermediate heat transfer layer between the Pt coil and the catalyst. ${ }^{7)}$ Although we have succeeded in developing the low temperature operative catalytic combustion-type $\mathrm{CO}$ gas sensor, the $10 \mathrm{wt} \% \mathrm{Pt} / \mathrm{Ce}_{0.68} \mathrm{Zr}_{0.17} \mathrm{Sn}_{0.15} \mathrm{O}_{2.0}$ catalyst contains precious metal of $\mathrm{Pt}$ whose consumed amount should be saved. In the light of practical use, especially in cost, it is desired to use the Pt-free catalyst.

From such a demand, in this study, we focused on $\mathrm{LaCoO}_{3}$ which has been reported to show catalytic activity toward $\mathrm{CO}$ oxidation and whose $\mathrm{CO}$ oxidation activity was improved by loading on the material with high surface area ${ }^{8}{ }^{8}$ and we developed a Pt-free CO oxidizing catalyst of $\mathrm{LaCoO}_{3}$-loaded $\mathrm{Ce}_{0.67} \mathrm{Zr}_{0.18} \mathrm{Sn}_{0.15} \mathrm{O}_{2.0}$. The $\mathrm{LaCoO}_{3}$-loaded $\mathrm{Ce}_{0.67} \mathrm{Zr}_{0.18} \mathrm{Sn}_{0.15} \mathrm{O}_{2.0}$ catalyst is expected to oxidize $\mathrm{CO}$ at low temperatures compared with other precious metal-free catalyst $^{9-11)}$ because the $\mathrm{Ce}_{0.67} \mathrm{Zr}_{0.18} \mathrm{Sn}_{0.15} \mathrm{O}_{2.0}$ support has not 
only high surface area but also to show the co-catalytic effect by the lattice oxygen migration similar to the $10 \mathrm{wt} \%$ $\mathrm{Pt} / \mathrm{Ce}_{0.68} \mathrm{Zr}_{0.17} \mathrm{Sn}_{0.15} \mathrm{O}_{2.0}$ catalyst. In this paper, we devised a catalytic combustion-type $\mathrm{CO}$ gas sensor using the $\mathrm{LaCoO}_{3}$ loaded $\mathrm{Ce}_{0.67} \mathrm{Zr}_{0.18} \mathrm{Sn}_{0.15} \mathrm{O}_{2.0}$ catalyst and investigated its sensing performance.

\section{Experimental}

The $\mathrm{Ce}_{0.68} \mathrm{Zr}_{0.17} \mathrm{Sn}_{0.15} \mathrm{O}_{2.0}$ solid solution was synthesized by the sol-gel method, as described in our previous paper. ${ }^{6}$ Then $\mathrm{LaCoO}_{3}$ was loaded onto the $\mathrm{Ce}_{0.68} \mathrm{Zr}_{0.17} \mathrm{Sn}_{0.15} \mathrm{O}_{2.0}$ support to yield 15.9 wt $\% \mathrm{La}_{0.87} \mathrm{Co}_{1.13} \mathrm{O}_{3}$-loaded $\mathrm{Ce}_{0.67} \mathrm{Zr}_{0.18} \mathrm{Sn}_{0.15} \mathrm{O}_{2.0}$ catalyst by the following procedure: $3.0 \mathrm{~mL}$ of $0.1 \mathrm{~mol} \mathrm{~L}^{-1}$ $\mathrm{La}\left(\mathrm{NO}_{3}\right)_{3}$ solution and $3.0 \mathrm{~mL}$ of $0.1 \mathrm{~mol} \mathrm{~L}^{-1} \mathrm{Co}\left(\mathrm{NO}_{3}\right)_{2}$ solution were added to the $0.36 \mathrm{~g}$ of $\mathrm{Ce}_{0.68} \mathrm{Zr}_{0.17} \mathrm{Sn}_{0.15} \mathrm{O}_{2.0}$ solid. Then $1.26 \mathrm{~mL}$ of $1.0 \mathrm{~mol} \mathrm{~L}^{-1}$ cytric acid solution and about $10 \mathrm{~mL}$ of deionized water were added and the mixed solution was stirred for $5 \mathrm{~h}$ at room temperature. After then, the solvent was removed off at $80^{\circ} \mathrm{C}$ by using hot stirrer and the obtained powder was heated at $140^{\circ} \mathrm{C}$ for $1 \mathrm{~h}$. The obtained powder was calcined at $700^{\circ} \mathrm{C}$ for $6 \mathrm{~h}$ in air.

The sample was identified by X-ray fluorescence (Rigaku, ZSX100e) and X-ray powder diffraction (XRD) (Rigaku, SmartLab) analyses with the $\mathrm{Cu}-\mathrm{K} \alpha$ line. $\mathrm{CO}$ oxidation activity of the $15.9 \mathrm{wt} \% \mathrm{La}_{0.87} \mathrm{Co}_{1.13} \mathrm{O}_{3}$-loaded $\mathrm{Ce}_{0.67} \mathrm{Zr}_{0.18} \mathrm{Sn}_{0.15} \mathrm{O}_{2.0}$ catalyst was investigated by a conventional fixed-bed flow reactor by flowing $1000 \mathrm{ppm} \mathrm{CO}$ diluted with air at the space velocity of $20000 \mathrm{~L} \mathrm{~kg}^{-1} \mathrm{~h}^{-1}$.

The sensor element was fabricated using a coil formed from $30 \mu \mathrm{m}$ diameter of Pt wire. Aluminum nitride (Toyo Aluminum K. K.) was dispersed in ethylene glycol to form a slurry and then, the slurry was loaded onto the Pt coil. After then, the coil was heated at approximately $300^{\circ} \mathrm{C}$ by applying a dc voltage of $2 \mathrm{~V}$ to evaporate the ethylene glycol. The $15.9 \mathrm{wt} \% \mathrm{La}_{0.87} \mathrm{Co}_{1.13} \mathrm{O}_{3}$-loaded $\mathrm{Ce}_{0.67} \mathrm{Zr}_{0.18} \mathrm{Sn}_{0.15} \mathrm{O}_{2.0}$ catalyst was dispersed in ethylene glycol and was coated over the AlN layer on the Pt coil and the ethylene glycol was

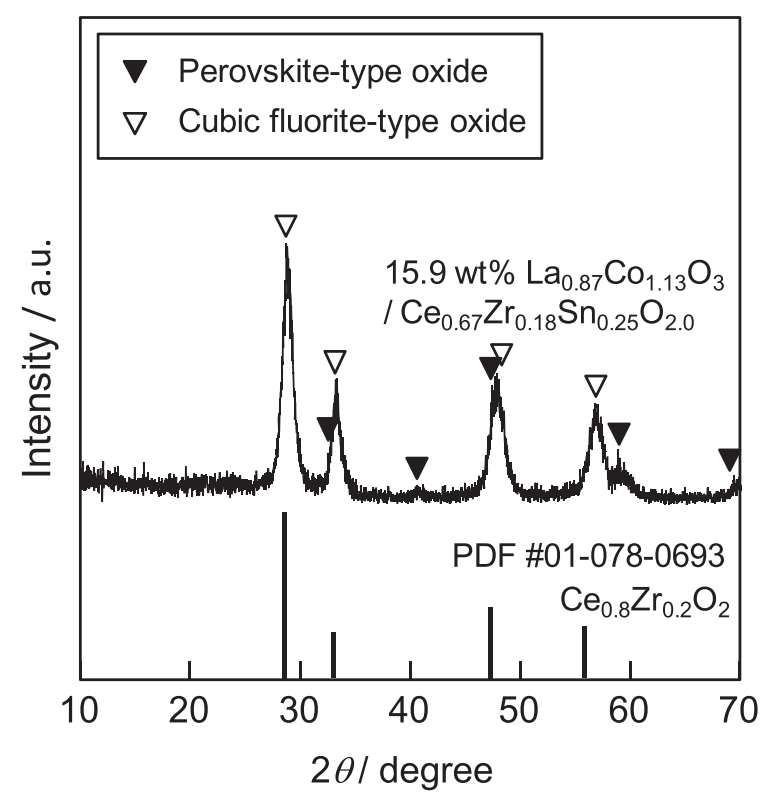

Fig. 1. XRD pattern for the $15.9 \mathrm{wt} \% \quad \mathrm{La}_{0.87} \mathrm{Co}_{1.13} \mathrm{O}_{3}$-loaded $\mathrm{Ce}_{0.67} \mathrm{Zr}_{0.18} \mathrm{Sn}_{0.25} \mathrm{O}_{2.0}$ catalyst. removed off by the same way described above. For an effective assessment of the AlN as an intermediate heat transfer layer, the volume ratio of AlN to catalyst was almost identical to that of the previous sensor employing $10 \mathrm{wt} \% \mathrm{Pt} /$ $\mathrm{Ce}_{0.68} \mathrm{Zr}_{0.17} \mathrm{Sn}_{0.15} \mathrm{O}_{2.0}{ }^{7)}$ The $\mathrm{CO}$ sensing performance of the sensor was investigated at $132^{\circ} \mathrm{C}$ by using an electrometer (Advantest, R8240) in the atmosphere whose CO gas concentration was varied from 0 to $500 \mathrm{ppm}$ that obtained by diluting 1000 ppm CO (Ar balance) gas with synthetic air. Regardless of the $\mathrm{CO}$ gas concentration, the total gas flow rate passing over the sensor was kept constant at $40 \mathrm{~mL}$ $\mathrm{min}^{-1}$. The sensor signal in response to exposure to $\mathrm{CO}$ gas was defined as $\left(\mathrm{R}_{\text {gas }}-\mathrm{R}_{\text {air }}\right) / \mathrm{R}_{\text {air }}$, where $\mathrm{R}_{\text {gas }}$ and $\mathrm{R}_{\text {air }}$ are the electrical resistances of the sensor in the test gas containing $\mathrm{CO}$ and in pure air, respectively. The sensor response time was defined as the time required for the electrical resistance of the device to reach $50 \%$ or $90 \%$ of the steady value eventually obtained at a given $\mathrm{CO}$ gas level.

\section{Results and Discussion}

We have confirmed that the cationic ratio ( $\mathrm{La}: \mathrm{Co}: \mathrm{Ce}$ : $\mathrm{Zr}: \mathrm{Sn}$ ) in the prepared solid was almost identical to the mixing one of the reactants by X-ray fluorescence analysis. From the XRD measurement of the $15.9 \mathrm{wt} \% \mathrm{La}_{0.87} \mathrm{Co}_{1.13} \mathrm{O}_{3}$-loaded $\mathrm{Ce}_{0.67} \mathrm{Zr}_{0.18} \mathrm{Sn}_{0.15} \mathrm{O}_{2.0}$ (The XRD pattern is shown in Fig. 1.), only peaks assigned to the cubic fluorite-type oxide and perobskite-type oxide without any crystalline impurities were clearly observed. Furthermore, the diffraction peak angles assigned to the cubic fluorite-type oxide were shifted slightly to higher angles as compared to those of $\mathrm{Ce}_{0.8} \mathrm{Zr}_{0.2} \mathrm{O}_{2.0}$ (PDF \#01-078-0693). These results clealy suggest that the celium (ionic radius of $\mathrm{Ce}^{3+}: 0.114 \mathrm{~nm}, \mathrm{Ce}^{4+}: 0.097 \mathrm{~nm}^{12)}$ ) ion sites in the $\mathrm{Ce}_{0.8} \mathrm{Zr}_{0.2} \mathrm{O}_{2.0}$ were partially substituted with smaller tin ions (ionic radius of $\mathrm{Sn}^{2+}: 0.093 \mathrm{~nm}, \mathrm{Sn}^{4+}: 0.071 \mathrm{~nm}^{13)}$ ) to form a solid solution, and the $15.9 \mathrm{wt} \% \mathrm{La}_{0.87} \mathrm{Co}_{1.13} \mathrm{O}_{3}$-loaded $\mathrm{Ce}_{0.67} \mathrm{Zr}_{0.18} \mathrm{Sn}_{0.15} \mathrm{O}_{2.0}$ solid was successfully obtained.

Figure 2 shows the $\mathrm{CO}$ oxidation activity of the $15.9 \mathrm{wt} \%$ $\mathrm{La}_{0.87} \mathrm{Co}_{1.13} \mathrm{O}_{3}$-loaded $\mathrm{Ce}_{0.67} \mathrm{Zr}_{0.18} \mathrm{Sn}_{0.15} \mathrm{O}_{2.0}$ catalyst. The pres-

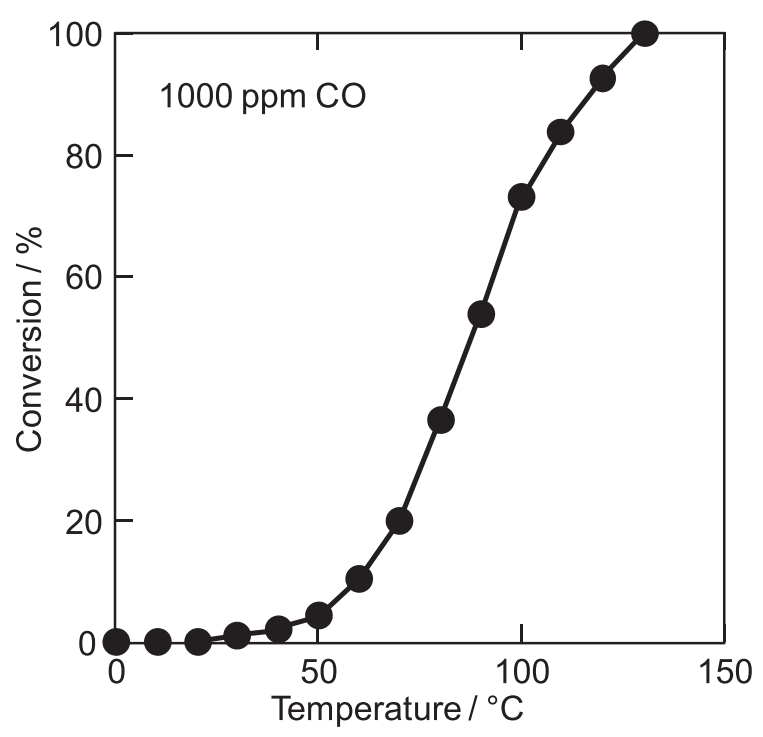

Fig. 2. Temperature dependence of the $\mathrm{CO}$ conversion to $\mathrm{CO}_{2}$ for the 15.9 wt $\% \quad \mathrm{La}_{0.87} \mathrm{Co}_{1.13} \mathrm{O}_{3}$-loaded $\mathrm{Ce}_{0.67} \mathrm{Zr}_{0.18} \mathrm{Sn}_{0.25} \mathrm{O}_{2.0}$ catalyst. 


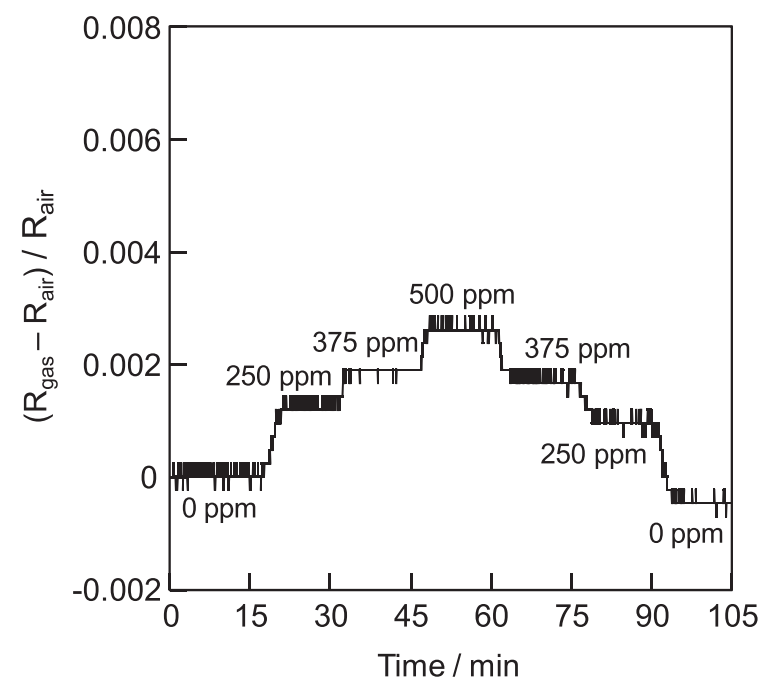

Fig. 3. Representative sensor response curve obtained by varying $\mathrm{CO}$ concentration from 0 to $500 \mathrm{ppm}$ and vice versa at $132^{\circ} \mathrm{C}$.

ent catalyst starts to oxidize $\mathrm{CO}$ at $30^{\circ} \mathrm{C}$ and complete oxidation is realized at $130^{\circ} \mathrm{C}$. Such high $\mathrm{CO}$ oxidation activity is considered to be realized by the co-catalytic effect of the $\mathrm{Ce}_{0.67} \mathrm{Zr}_{0.18} \mathrm{Sn}_{0.25} \mathrm{O}_{2.0}$ support. Lattice oxygen in the support may migrate easily to the surface through the lattice oxygen vacancies generated by the existence of a certain amount of $\mathrm{Sn}^{2+}$ ion. ${ }^{14)}$ As a result, oxygen migrated to the surface also work for the $\mathrm{CO}$ oxidation. From this result, we can expect that the sensor detect $\mathrm{CO}$ gas concentration quantitatively above $130^{\circ} \mathrm{C}$ even in the absence of precious metal.

Figure 3 displays a representative response curve for the present sensor with the $15.9 \mathrm{wt} \% \mathrm{La}_{0.87} \mathrm{Co}_{1.13} \mathrm{O}_{3}$-loaded $\mathrm{Ce}_{0.67} \mathrm{Zr}_{0.18} \mathrm{Sn}_{0.15} \mathrm{O}_{2.0}$ catalyst and the $\mathrm{AlN}$ intermediate heat transfer layer obtained when the $\mathrm{CO}$ gas concentration was varied from 0 to $500 \mathrm{ppm}$ and vice versa in a step-by-step manner at $132^{\circ} \mathrm{C}$. The sensor signal $\left(\left(\mathrm{R}_{\mathrm{gas}}-\mathrm{R}_{\mathrm{air}}\right) / \mathrm{R}_{\mathrm{air}}\right)$ changed smoothly and reproducibly with varying the $\mathrm{CO}$ gas concentration. Furthermore, the $50 \%$ and the $90 \%$ response time were $20-40 \mathrm{~s}$ and $50-100 \mathrm{~s}$, respectively, which are similar to those (20-30 s and $90 \mathrm{~s})$ of our previously reported sensor employing $10 \mathrm{wt} \%$ precious $\mathrm{Pt} /$ $\mathrm{Ce}_{0.68} \mathrm{Zr}_{0.17} \mathrm{Sn}_{0.15} \mathrm{O}_{2.0}$ and $\mathrm{AlN}$ intermediate layer. ${ }^{7)}$

Figure 4 depicts the steady-state sensor signals at various $\mathrm{CO}$ gas concentrations at $132^{\circ} \mathrm{C}$. Similar to the previous sensor reported by us, ${ }^{7)}$ the present sensor produces a signal which varies in a linear fashion with changing the CO gas concentration, suggesting that the present sensor can detect $\mathrm{CO}$ concentration quantitatively. Although the operation temperature of the present sensor is higher than that of the previous sensor with $\mathrm{Pt}$ loaded catalyst, ${ }^{7)}$ it is quite lower than those $\left(250-400^{\circ} \mathrm{C}\right)$ of conventional sensors with precious metal-loading $\mathrm{Pt} / \mathrm{Al}_{2} \mathrm{O}_{3}$ or $\mathrm{Pd} / \mathrm{Al}_{2} \mathrm{O}_{3}$ catalyst. Moreover,

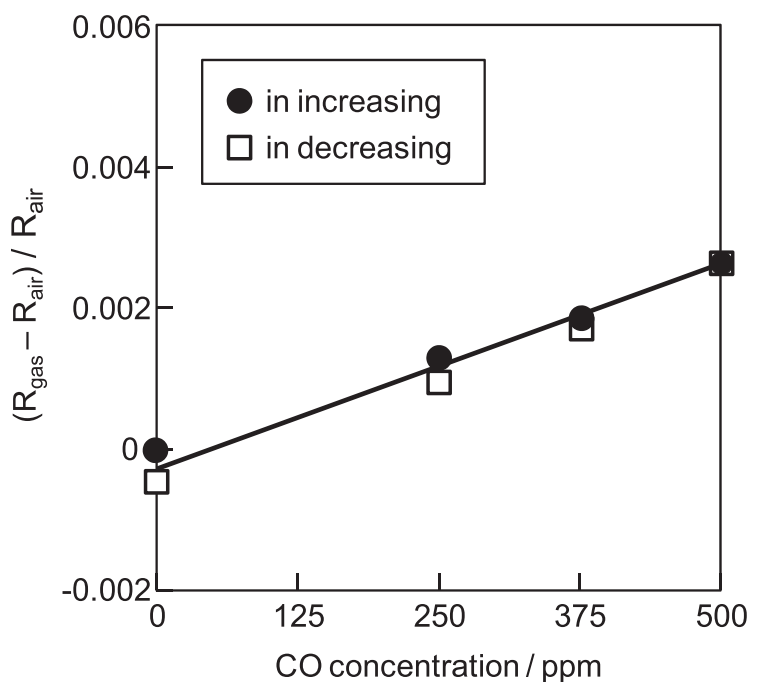

Fig. 4. Sensor signals at various $\mathrm{CO}$ concentrations for the present sensor incorporating the $15.9 \mathrm{wt} \% \quad \mathrm{La}_{0.87} \mathrm{Co}_{1.13} \mathrm{O}_{3}$-loaded $\mathrm{Ce}_{0.67} \mathrm{Zr}_{0.18} \mathrm{Sn}_{0.25} \mathrm{O}_{2.0}$ catalyst and $\mathrm{AlN}$ intermediate heat transfer layer at $132^{\circ} \mathrm{C}$.

the present sensor has a merit of cost performance because the present sensor employed precious-metal free catalyst of 15.9 wt $\% \mathrm{La}_{0.87} \mathrm{Co}_{1.13} \mathrm{O}_{3}$-loaded $\mathrm{Ce}_{0.67} \mathrm{Zr}_{0.18} \mathrm{Sn}_{0.15} \mathrm{O}_{2.0}$ having the similar quick response to our previous sensor with Pt-loaded catalyst. ${ }^{7)}$ From these advantages, the present sensor is considerd to be another candidate for the practical $\mathrm{CO}$ detecting tool.

\section{Acknowledgments}

Present work was partially supported by the working group of WSN (Wireless Sensor Network 2012-2015) supported by The Iron and Steel Institute of Japan and by a Grant-in-Aid for Science Research (No. 24655193) from the Japan Society for the Promotion of Science.

\section{REFERENCES}

1) W. Göpel and K. D. Schierbaum: Sens. Actuat. B, 26 (1995), 1.

2) G. Korotcenkov: Sens. Actuat. B, 121 (2007), 664.

3) K. F. Blurton and J. R. Stetter: J. Chrom., 155 (1978), 35.

4) M. Sakaguchi, A. Ishikawa and I. Hoshihara, J. Comb. Soc. Jpn., 51 (2009), 129.

5) T. Ozawa, Y. Ishiguro, K. Toyoda, M. Nishimura, T. Sasahara and T. Doi: Sens. Actuat. B, 108 (2005), 473.

6) A. Hosoya, S. Tamura and N. Imanaka: Chem. Lett., 42 (2013), 441.

7) A. Hosoya, S. Tamura and N. Imanaka: J. Sens. Sens. Syst., 3 (2014), 141.

8) X. Yan, Q. Huang, B. Li, X. Xu, Y. Chen, S. Zhu and S. Shen: $J$. Ind. Eng. Chem., 19 (2013), 562.

9) G. Xanthopoulou and G. Vekinis: Appl. Catal. B, 19 (1998), 37.

10) A. V. Salker and S. M. Gurav, J. Mater. Sci., 35 (2000), 4713.

11) H. Zhong, X. Zeng, L. Luo and D. Liu: React. Kinet. Catal. Lett., 87 (2006), 139.

12) R. D. Shannon: Acta Cryst., A32 (1976), 751.

13) L. H. Ahrens: Geochem. Cosmochem. Acta, 2 (1952), 155.

14) K. Yasuda, A. Yoshimura, A. Katsuma, T. Masui and N. Imanaka: Bull. Chem. Soc. Jpn., 85 (2012), 522. 